\title{
TORS OF THE CHOCHOLOWSKA VALLEY (WESTERN TATRA MOUNTAINS)
}

\author{
EWA LUBERA \\ Institute of Geography and Spatial Management \\ Jagiellonian University \\ Gronostajowa 7, 30-387 Kraków, Poland \\ E-mail: ewa.1ubera@uj.edu.pl
}

\begin{abstract}
The paper contains the characteristics of selected tors of the Chocholowska Valley, taking into account their geological structure, morphological location, aspect, morphometrics, shape and microrelief of the surface of rock walls, as well as position in the altitudinal climate-vegetation belt. It is shown that individual tor groups are typified by low mutual similarity.
\end{abstract}

Key words: tors, development stages, the Chochołowska Valley, the Tatra Mts., Poland

\section{INTRODUCTION}

The rock landforms in the Tatra Mountains were created under the conditions of periglacial climate, during the Pleistocene mountain glaciation of the Tatra Mountains. At that time, intense frost weathering, rock falls and solifluction were taking place, leading to slope remodeling, formation of weathering covers and exhumation of resistant bedrock structures, i.a. in the form of tors and other rock forms (Klimaszewski 1988). In the Holocene and up to now, these landforms have undergone continuous re-shaping due to physical, chemical and biological weathering, rockfall and karst processes. This results in the change of shape, size, degree of dismembering and fracturing, as well as development of surficial microrelief, specific for individual rock type. Permanent activity of destructive processes leads to gradual degradation of the analyzed landforms.

Tors, depending on their location in a given climate-vegetation belt and absolute height as well as geological structure of the bedrock (including its susceptibility to dif- ferent geomorphic processes and degree of fracturing) are being shaped in various ways.

\section{PURPOSE OF STUDY}

The purpose of this study was to elaborate comparative characteristics of the selected tors located in the Chocholowska Valley. The following elements were taken into consideration: geomorphic location, morphometry, shape, aspect, geological structure, and microrelief. Furthermore, an attempt was made to determine the development stages of tors and to indicate their main presently active modeling processes.

\section{PREVIOUS STUDIES}

Tors have been subject to geomorphic research for a long time. In some papers, emphasis is put on the origin of landforms, while in others researchers focus on the characteristics of rocks present in an area. Many papers include classification of tors. 
The studies aiming at reconstructing the origin of tors have been carried out, among other places, in: the Carpathian Foothills (Klimaszewski 1932), Stolowe Mountains (Czeppe 1952, Walczak 1963), Roztocze region (Kęsik 1955), Central England (Palmer and Radley 1961), Karkonosze Mountains (Jahn 1962), Pieklo Mountain (Holy Cross Mts.) in the vicinity of Nieklan (Lindner 1972), Gorce Mountains (Z. Alexandrowicz 1982), Dartmoor Massif in England (Bajgier 1991), as well as in the KrakowCzęstochowa Upland (S. W. Alexandrowicz and Z. Alexandrowicz 2004).

Individual authors paid attention to different processes that shape the rocks, namely: mechanical, chemical and biological weathering (King 1948; Linton 1955; Czeppe 1952; Walczak and Stec 1954; Palmer and Radley 1961; Z. Alexandrowicz 1964, 1982; Jahn 1985), corrasion, and deflation (Klimaszewski 1932; Lindner 1972). Attention was also paid to the role of petrographic diversity - mineralogical composition, structure, bedding, fracturing - resulting in a different susceptibility of rocks to the impact of geomorphic processes and leading to selective rock destruction (Czeppe 1952; Kęsik 1955; Walczak 1963; Jahn 1985; S. W. Alexandrowicz and Z. Alexandrowicz 2004). On the other hand, M. Klimaszewski (1932) emphasized the role of water in the modeling of rocks, both rainfall water protruding into fissures, and capillary waters.

Development of rock landforms, mainly tors, is also related to slope processes. The direct initiator of development of tors are mass movements: the sliding material exposes rock walls that undergo, i.a., frost weathering fostering rockslides and, consequently, scarp retreat (Palmer and Radley 1961). A. Jahn (1962) ascertained that tors represent landforms produced due to selective denudation and that the "tor component" must have existed below the groundsurface before being exposed morphologically. From the moment of exhumation, such landforms have not changed much their shape. Also, Z. Alexandrowicz (1982) pointed to denudational origin of tors, basing on a study in the Gorce Mountains. Tors were created as a result of weathering and erosion, leading to the lowering of ridges and slope retreat. Some tors are landslide-related landforms or their origin is related to valley head formation (Z. Alexandrowicz ed. 1996).

Numerous studies of tors aimed at determination of the time of their creation and related climatic conditions. M. Klimaszewski (1932) associated the origin of tors in the Carpathian Foothills with the postglacial period. J. Palmer and J. Radley (1961) concluded that the formation of tors in central England is one of the effects of slope processes active in periglacial conditions. A. Jahn (1962), while examining the tors of the Karkonosze Mountains, stated that these were mostly landforms pre-dating the last glaciation, although those separated in postglacial time are also present. W. Walczak (1963) concluded that the tors in the Stolowe Mountains were of late Pleistocene age, remodeled in the postglacial period and presently undergoing a slow destruction. L. Lindner (1972) associated the main cycle of corrasion-deflational modeling of tors of the Pieklo Mountain with the long-term activity of westerly winds in the period of accumulation of younger loesses in the Holy Cross Mts. region. M. Bajgier (1991), on the basis of studies of tors in the Dartmoor Massif, England, indicated that the hilltop monadnocks represent Tertiary weathering monadnocks, altered in periglacial climate; though younger, Quaternary landforms shaped in a periglacial climate are also present. S.W. Alexandrowicz and Z. Alexandrowicz (2004) maintain that the examined tors of the Kraków-Częstochowa Upland originated in the Palaeogene and became remodeled, first in the Pleistocene, under periglaciàl climatic conditions, and then in the Holocene.

The studies of tors have also resulted in a number of models explaining the shaping of these landforms. The single-phase model of L. C. King (1948) assumes the existence of one continuous period of rock landform creation. Both weathering and removal of waste covers occur at the same time. The 
main process responsible for the creation of rock landforms is pediplanation.

According to an alternative, two-phase model of D. Linton (1955), rocks are created in two separate phases. The first phase covers intensive subsurface chemical weathering under the conditions of high humidity and warm climate during the Palaeogene and Neogene. In the second phase of intensive degradation of weathering covers, the removal of accumulated material takes place. L. Lindner (1972) also indicated a two-stage creation of tors, on the basis of studies of the Piekło Mountain, Holy Cross Mts. In the first stage, the processes of corrasion and deflation resulted in separation of more silicified parts of the Liassic bedrock, whereas in the second stage, using joints and fault zones, they resulted in the separation of different mushroom-like rocks and ledges. Also the studies of A. Jahn (1985), conducted in the Karkonosze Mountains, resulted in distinguishing two phases of tor formation. The first stage consisted in a deep, subsurface chemical weathering, taking place in warm and humid climate of the early Tertiary. The second stage resulted in the removal of waste cover and rock exhumation related to the uplift of the Karkonosze Mountains.

Another group of papers deal with detailed characteristics of tors and their classification. Such studies were carried out in the Holy Cross Mountains (Czarnocki 1932), Carpathian Foothills (Klimaszewski 1932; Drzal 1955a, b; Z. Alexandrowicz 1970), Outer Carpathians (Klimaszewski 1947; Dudziak 1960; Z. Alexandrowicz 1963a, b, c, 1964a, b; Z. Alexandrowicz 1982; Z. Alexandrowicz ed. 1996; Bajgier-Kowalska 2002), Karkonosze Mountains (Walczak and Steć 1954), Silesian Upland (Hornig 1955), Kraków Upland (S. W. Alexandrowicz and Z. Alexandrowicz 2003), Western Tatra Mountains (Wieczorek 1999), and Middle Sudetes Mountains (Migoń 2005).

Emphasis was put on determining the shape of tors, their dimensions and geological structure. Sometimes, additional elements were also taken into account, like: the aspect and degree of vegetation coverage
(Czeppe 1952), geomorphic position (Z. Alexandrowicz 1982), location in the altitudinal vegetation belt, and fracturing (Wieczorek 1999). The role of slope dissection by dellen and gullies upon the height and shape of tors were analyzed as well (Walczak 1963).

A lot of attention was paid to the description of microforms present on the surface of rocks and the study of reasons for their creation. Spongy structures, bowl-like cavities and pocket cavities (Kęsik 1955), crusts, arcade structures, gypsum and alum efflorescences (Z. Alexandrowicz ed. 1996), and rock niches and rock shelves were distinguished (S. W. Alexandrowicz and Z. Alexandrowicz 2004). Z. Alexandrowicz indicated that the microrelief is a phenomenon depending mainly on structures and resistance of the rock (type and quantity of cement, hardness of particular components and grain size).

The relationships between the dimensions and shape of individual tors and their bedrock have also been examined. A. Sobczyk (2008) obtained a strong positive correlation ( 0.81$)$, illustrating the relation between Rock Mass Strength value and the height of particular rocks.

As a result of detailed studies, different classifications of tors have been proposed. A. Jahn (1962) distinguished three types of granite tors in the Karkonosze Mountains, namely the mesa, tower rock and block ones. M. Klimaszewski (1947) developed a classification of the Carpathian rocks, including: rock towers and ledges, rock pulpits, and mushroom-like rocks. Z. Alexandrowicz (1970) presented another classification of tors, observed in the Carpathian Mountains, by distinguishing 15 types: rock pulpit, rock tower, rock cudgel, mushroom rock, rock platform, rock plate, rock table, rock wall, rock face, rock barrier, rock step, ledge, rock overhang, rock blocks and block fields. Z. Alexandrowicz and E. Brzeźniak (1989) distinguished three main types of sandstone-conglomeratic rocks landforms of the Flysch Carpathians characterized by different morphological profiles of their walls: concave - strongly convex - poorly or strong- 
ly convex, strongly convex - poorly concave - poorly convex, and convex - strongly concave - strongly convex. On the other hand, M. Bajgier-Kowalska (2002) proposed to distinguish several types of the Beskidy tors related to the development of landslides, including, i.a., tors on the slopes of ridge-top trenches, tors on walls of rockslide niches, rock pulpits or tower rocks on walls of rockslide niches, and tors arranged staircase-like upon niches of rotational landslide packets.

Moreover, review papers dealing with monuments of inanimate nature in Poland
(Z. Alexandrowicz et al. 1975), or summarizing the state-of-the-art concerning rocky landforms, particularly in the Sudety Mts. (Sobczyk 2006), were published as well.

\section{STUDY AREA AND METHODS}

Field studies were conducted in the Chocholowska Valley, the westernmost and largest of main valleys in the Polish part of the Tatra Mountains (Fig. 1-I). The valley occupies an area of $34.78 \mathrm{~km}^{2}$, and its

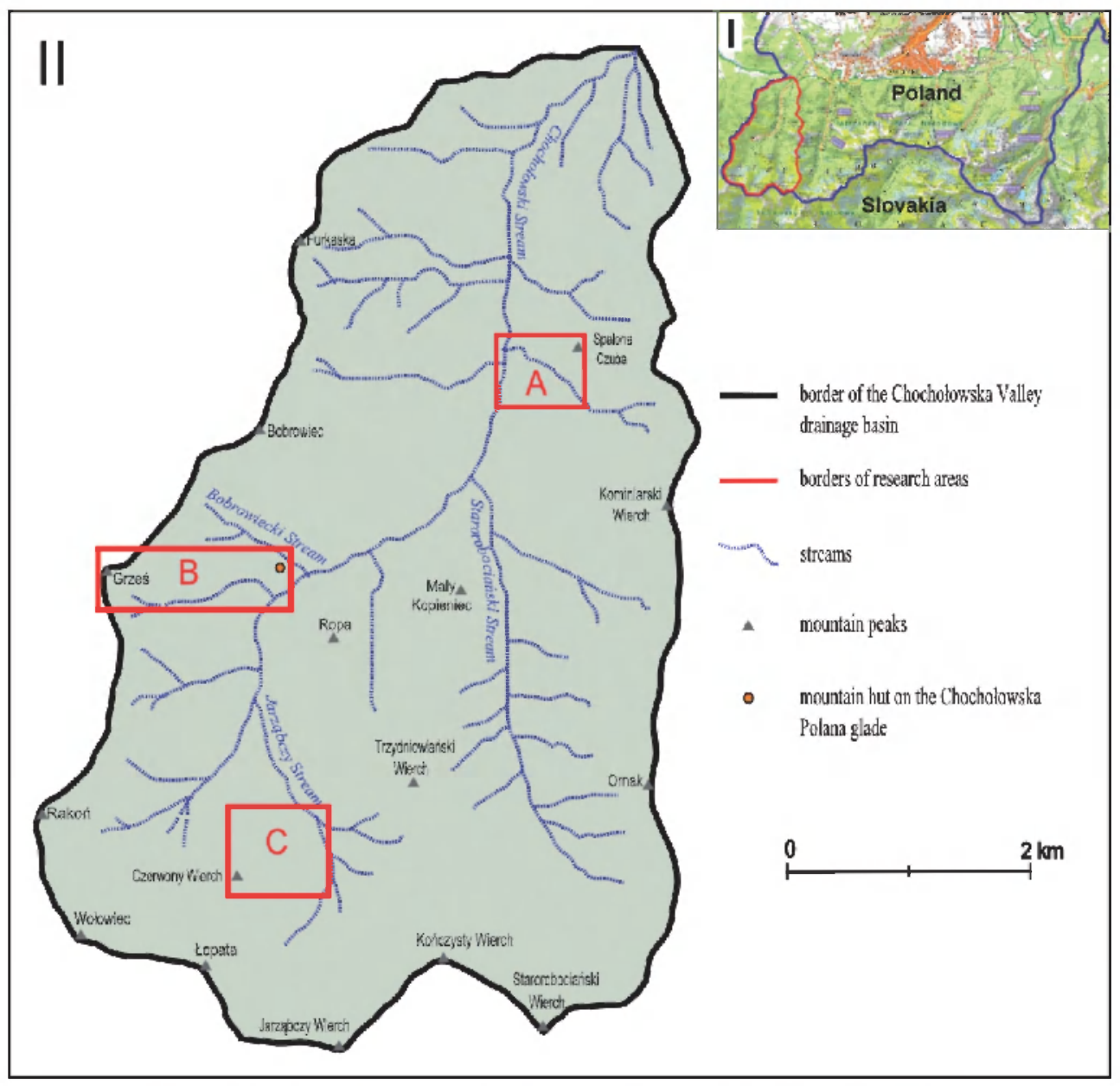

Figure 1. I-Location of the Chocholowska Valley in the Tatra Mountains,

II - Location of study sites in the Chocholowska Valley:

A - Dudowa Valley, B - Grześ Mt., C-Czerwony Wierch Mt. 
the length is $9.7 \mathrm{~km}$ (Klimaszewski, 1988). In the upper part, the Chocholowska Valley is subdivided into three branches: the Wyżnia Chocholowska, the Jarząbcza, and the Starorobociańska valleys.

Measurements of 76 tors located in three selected study sites of the Chocholowska Valley were taken, namely: in the bottom part of the Dudowa Valley (39 forms), on the eastern slope of the Grześ Mt. (17 forms), as well as on the north-eastern slope of the Czerwony Wierch Mt. (20 forms; Fig. 1-II). Detailed geomorphological mapping at the scale of 1:5,000 was also performed (Figs. 2, $7,10)$.

During field studies, the following parameters were taken into account: the height of tors, width, length and microrelief of rock walls, aspect, geomorphic position, location in a given climato-vegetational belt and degree of vegetation coverage.

Measurement tape, geologic compass and inclinometer were used. Photographic documentation was also made. The height of tors was determined using the measurement tape, and, in the event when it was not possible, an inclinometer was applied. For further calculations, the following formula was applied:

$$
\mathrm{h}=\mathrm{d} \operatorname{tg} \alpha
$$

where:

$h$ - the height of tor,

$\mathrm{d}$ - the distance from tor to inclinometer, $\alpha$ - the angle read from the inclinometer, between the base of tor and its top.

In order to characterize the geological structure of the examined landforms, samples for petrographic analysis under an optical microscope were collected. The analyses were carried out in the Institute of Geological Sciences of the Jagiellonian University.

\section{ROCKS OF THE CHOCHOŁOWSKA VALLEY}

\section{THE DUDOWA VALLEY STUDY SITE}

Tors found in the Dudowa Valley are very numerous and cluster in the bottom part of the valley: mostly in the Międzyściany
Gorge and in the upper part of the valley, on the valley side showing the northern aspect ("Kościól", "Dudowe Spady", and "Skrzynie" sites). The examined rocks are situated: at the mouth of the Dudowa Valley (form no. 39), in the Międzyściany Gorge (forms no. 1-36 and 38), and west of the Wyżnia Dudowa Rówień clearing (form no. 37, Fig. 2).

Tors found in the Międzyściany Gorge are arranged asymmetrically: on the right-hand side of the gorge 30 forms are located compared to 7 on the left-hand side. Rocks are located mainly upon narrow ridges, separated from each other by short denudation valleys (up to $130 \mathrm{~m}$ long) of fairly high gradient and showing rocky, uneven bottom (Fig. 2).

A dominant type of tors in the Międzyściany Gorge is a rock tower and a pulpit (Fig. 3); there also are 2 rock spires (forms nos. 24, 26), 2 cudgels (forms nos. 9, 34), and 1 karst bridge (form no. 7; Fig. 4). The remaining 2 landforms, located outside the Międzyściany Gorge, represent castle rocks (Fig. 2).

All tors located in the Międzyściany Gorge and form no. 39 are built up of ash-grey, brecciated, crystalline-type and showing chaotic structure dolomites of the Middle Triassic of the Lower Sub-Tatric Series. Form no. 37 is composed of the Malm-Neocomian limestones of the High-Tatric Series, typified by greater resistance, as shown by the size $(10 \times 25 \times 100 \mathrm{~m})$ and massive structure of the discussed form.

The majority of tors are characterized by differentiated microrelief of their wall surfaces. The most numerous are clusters of crater-like depressions, karren separated by small ridges of rounded crests (Fig. 5), and agravitational dripstones - mushrooms (Fig. 6). Caves and rock shelters occur within tors nos. 25, 26, 27, 36 and 37.

\section{THE GRZEŚ MOUNTAIN STUDY SITE}

The examined rock landforms and block fields, located on the slope of the Grzes Mountain, form four largely-spaced clusters (Fig. 7). As far as the shape is concerned, landforms of the tower rock type clearly dominate (Fig. 8); there also are 1 rocky 


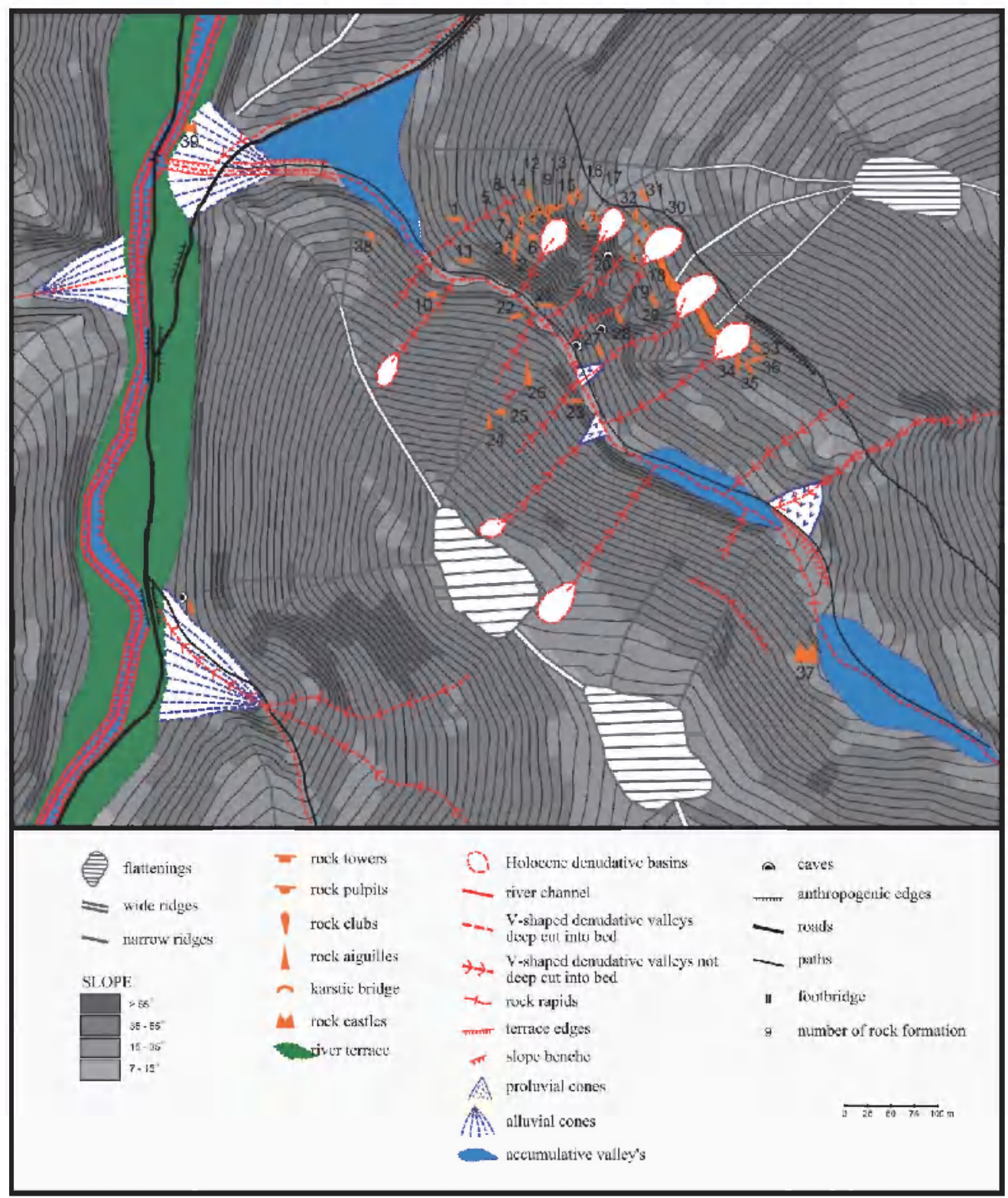

Figure 2. Geomorphological map of the lower part of the Dudowa Valley

Legend to geomorphological maps - cf. Figs. 2, 7, 10

ridge (form no. 7) and 3 block fields (forms nos. 2, 6, 13). Block fields occupy an area of approximately 20 to more than $340 \mathrm{~m}^{2}$. Individual clasts attain $30 \mathrm{~cm}$ in diameter. Scarce landforms, difficult to classify unequivocally, were called rock groups (Figs. 7,9).
Except for landforms nos. 11 and 12, which are built up of andesine-biotite gneisses of the crystalline series, all rocks located on the Grzes Mt. are composed of the Lower Triassic quartzitic sandstones of the High-Tatric Series. The sandstones 


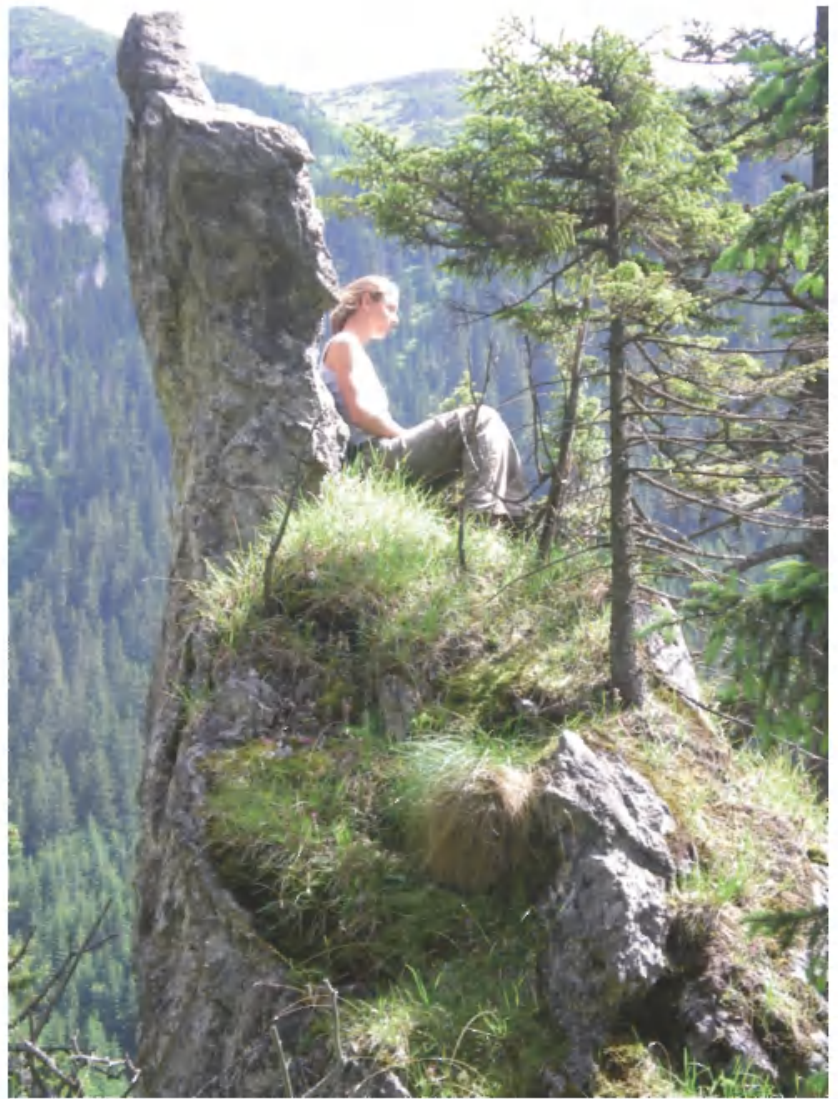

Jiggure 3. Pulpit "throme" (pholograph by $\Lambda$. Wolanin)

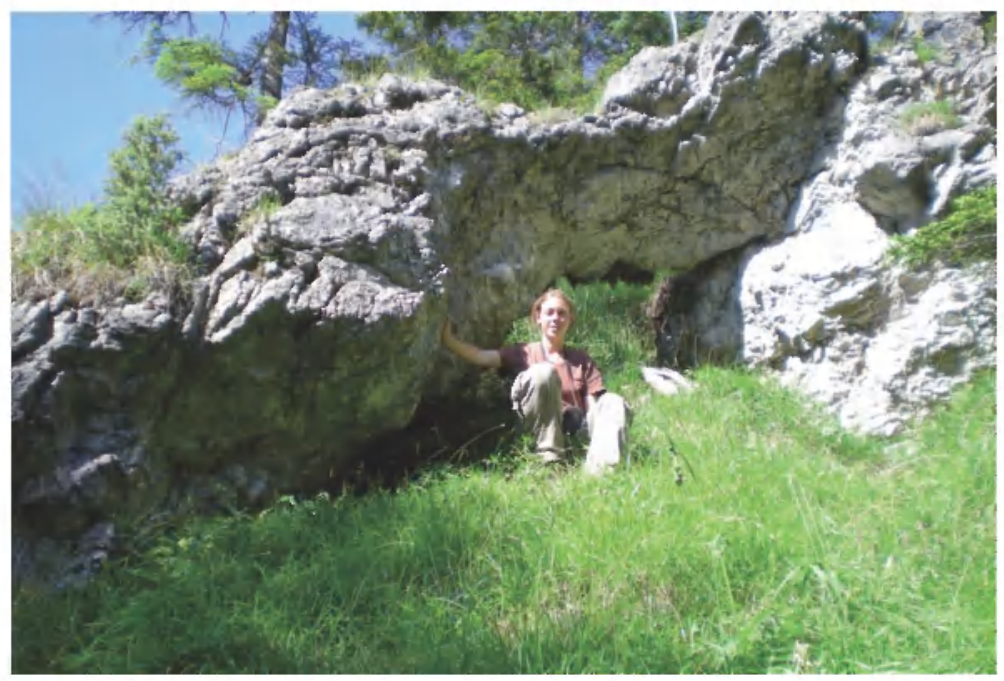

Figure 4. Karst bridge (photograph by A. Wolanin) 


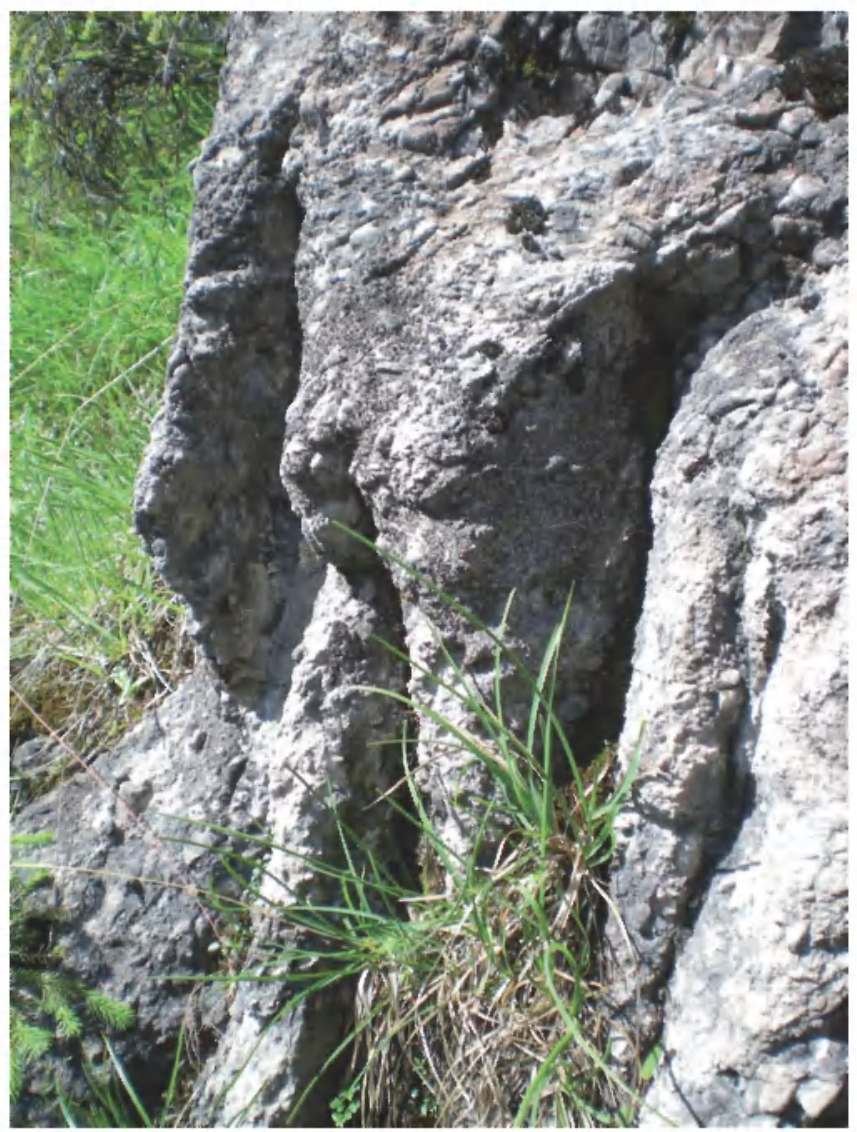

l'igure 5. Karren

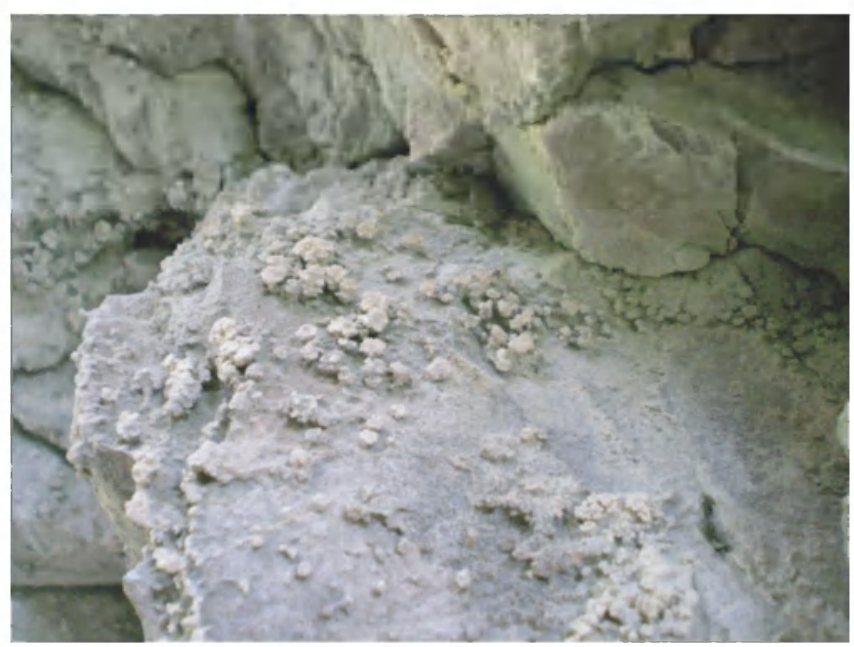

Figure 6. Agravitational dripstones - mushrooms 


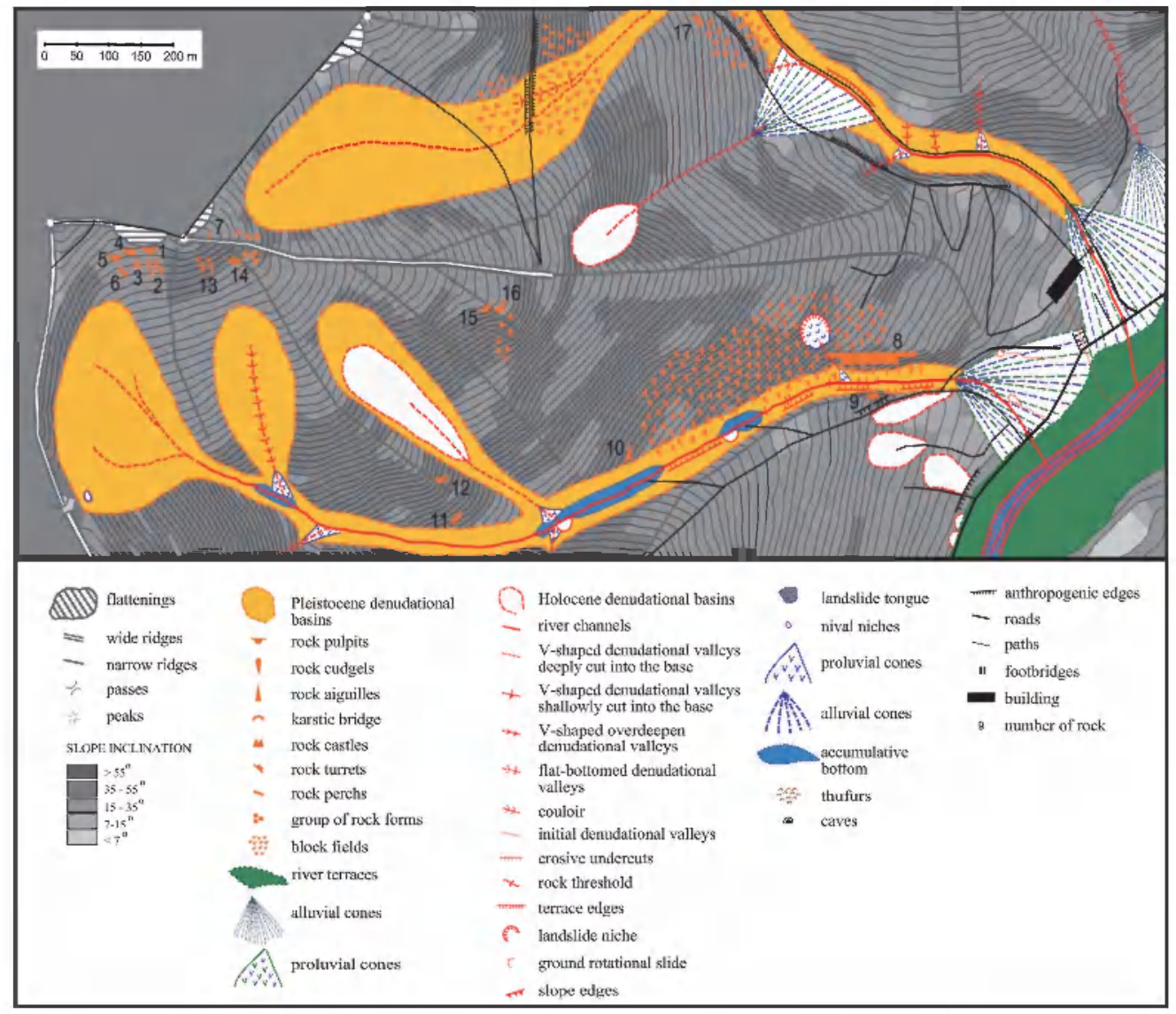

Figure 7. Geomorphological map of the eastern slope of the Grzes Mt.

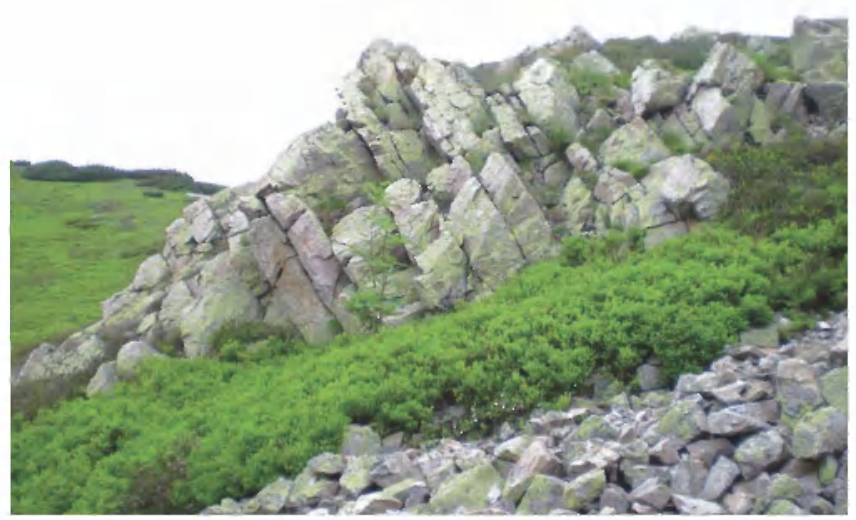

Figure 8. One of rock towers located on the slope of the Grzes Mt., above the upper timber line 


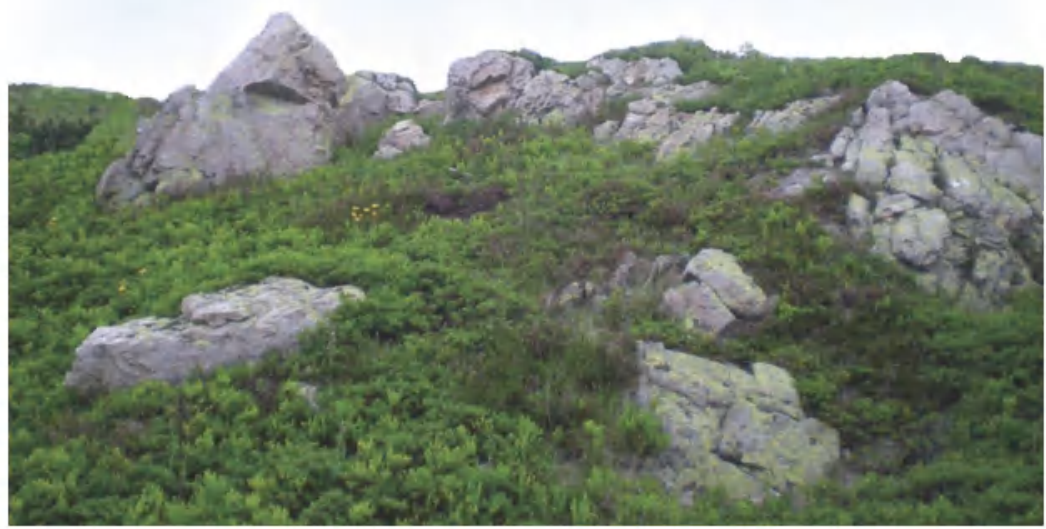

Figure 9. Landform classified as a rock group

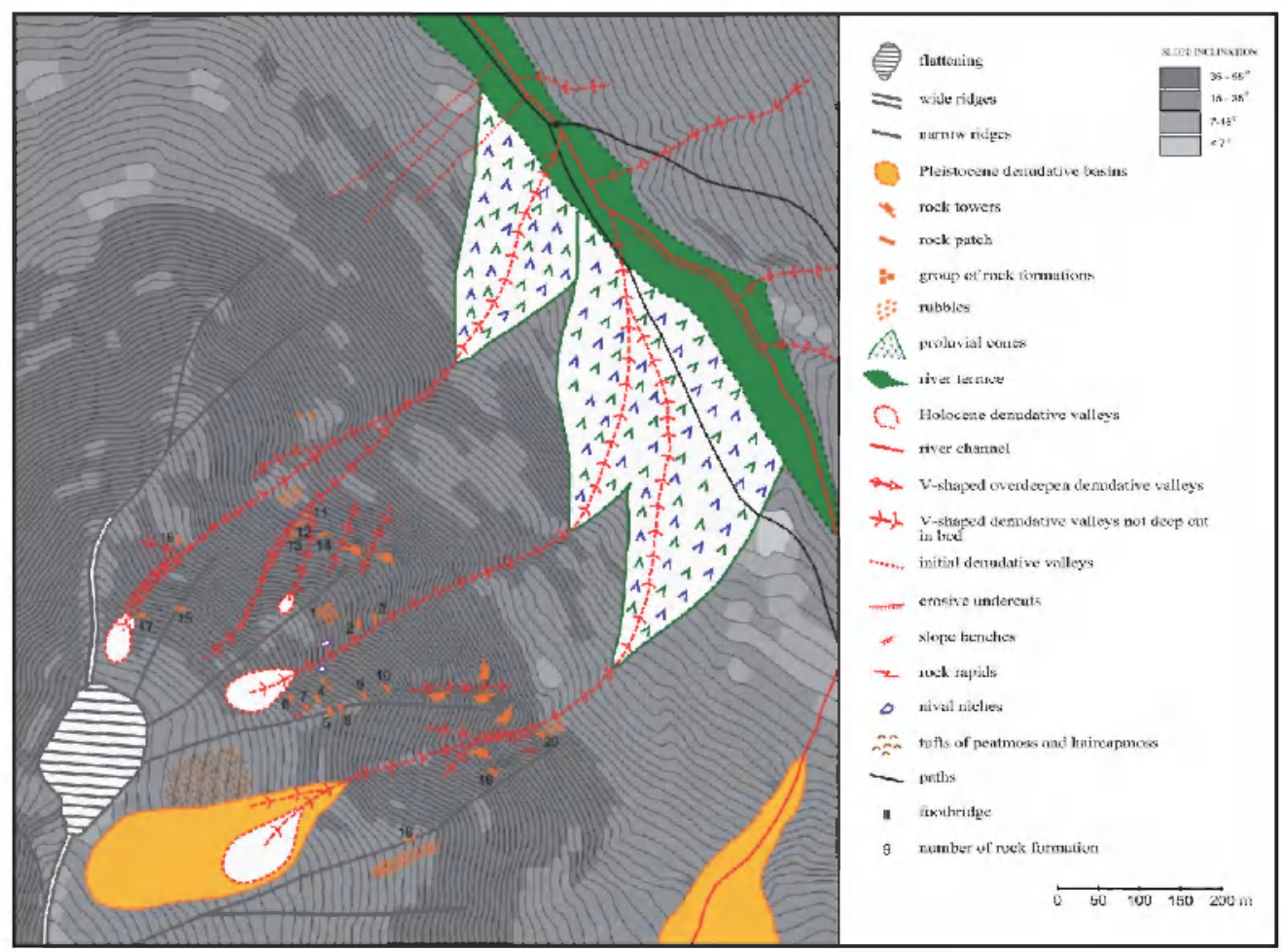

Figure 10. Geomorphological map the north-eastern slope of the Czerwony Wierch Mt. 
consist mainly of monomineral, less frequently mosaic quartz of metamorphic origin. Quartzose matrix and siliceous cement enriched in clayey material dominate.

The mapped slope of the Grześ Mt. is a perfect example of the relationship between relief and geological structure. All exposures of very resistant quartzitic sandstones are accompanied by tors.

\section{THE CZERWONY WIERCH MT. STUDY SITE}

Tors situated on the slope of the Czerwony Wierch Mt. are numerous and concentrate in the vicinity of the three largest gullies cutting the slope, namely: the Mokrzyniec, Pośredni Żleb and Skrajny Żleb gullies. Twenty tors were measured; half of them being located on either side of the Pośredni Zleb gully, as well as on a side ridge between the Pośredni Żleb and Mokrzyniec gullies (Fig. 10). Some landforms were not examined owing to limited accessibility (Fig. 10 - rocks without numbering).

As far as the shape is concerned, rock towers dominate (18 forms; Fig. 11). One rocky ridge (form no. 18; Fig. 12) and one block field (form no. 1) are also present. The size of the latter is $19 \times 25 \mathrm{~m}$ and its clast diameters range between a few centimeters and ca. $3 \mathrm{~m}$.

All the examined tors are built up of white granitogneisses of the crystalline series, showing oriented structure.

\section{DIVERSITY OF TORS IN THE CHOCHOŁOWSKA VALLEY}

The examined tors are located mainly on side ridges or valley sides. Additionally, in the Dudowa Valley and on the Grześ Mt., these landforms are located also at the bottom of the trunk valley or tributary gullies. Slopes occupied by tors are usually inclined at $35-45^{\circ}$ in the Dudowa Valley and on the Czerwony Wierch Mt., and $24-35^{\circ}$ on the Grześ Mt.. The rocks show different aspects: $\mathrm{S}$ on the Grześ Mt., NE and $\mathrm{N}$ on the Czerwony Wierch Mt., and SW in the Dudowa Valley (Fig. 13). The aspect of tors results from that of host slopes and is also controlled by geological structure.

Differences among tors result mainly from diversified geological structure. Landforms composed of granitogneisses (Czerwony Wierch) and quartzitic sandstones (Grześ),

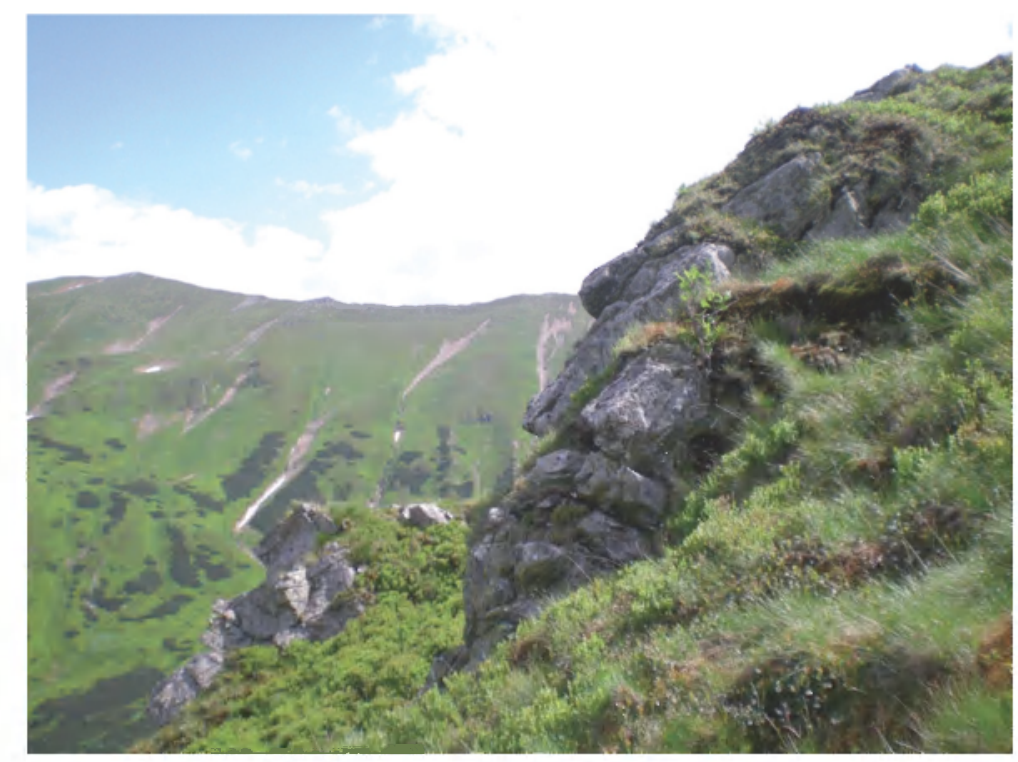

Figure 11. Rock tower on the slope of the Czerwony Wierch Mt. 


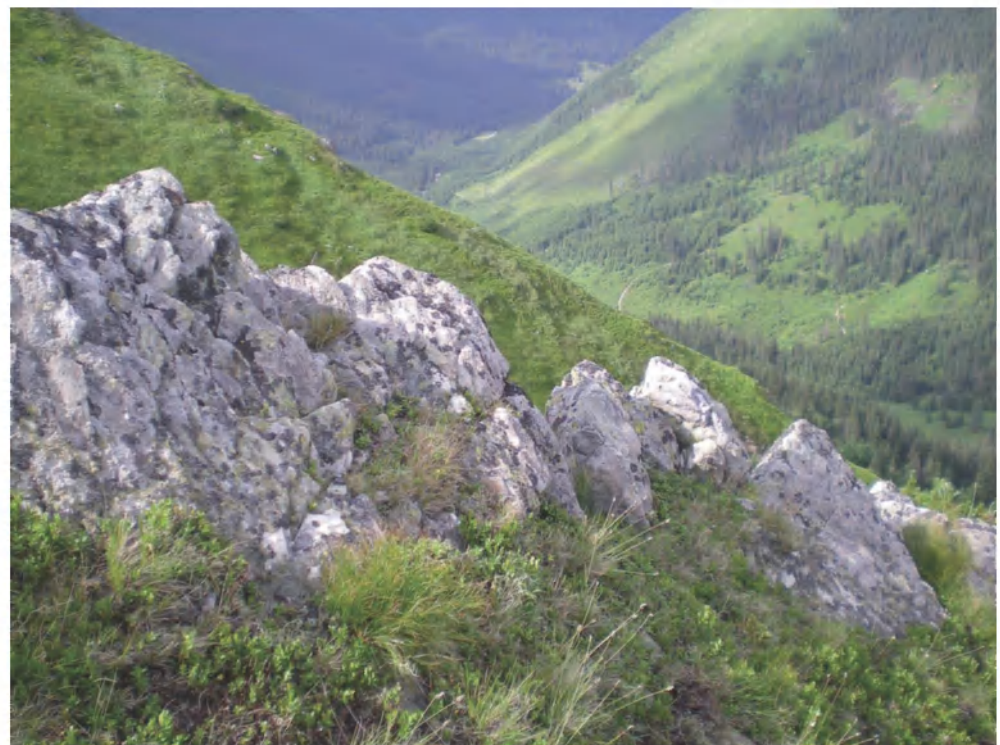

Figure 12. Rocky ridge siluated on the side ridge of the Czerwony Wierch Mt.

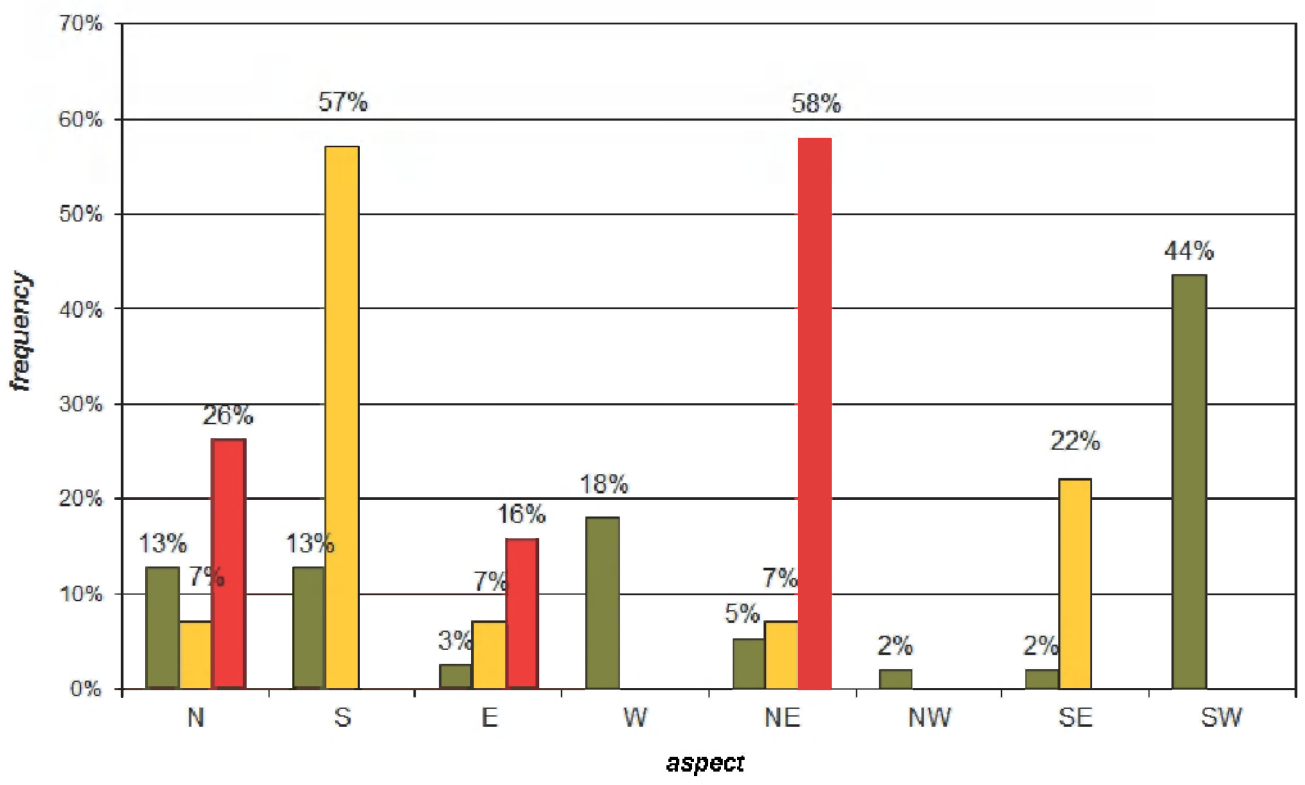

athe Dudowa Valley $\square$ the Mt. Grzes a the Mt. Czerwony Wierch

Figure 13. Aspect of tors at particular study sites

due to predominance of quartz (sandstone and granitogneiss) as well as muscovite and biotite (granitogneiss), i.e. minerals resistant to weathering (Whalley and Warke 2005), are being altered much more slowly compared to dolomitic tors of the Dudowa Valley. 


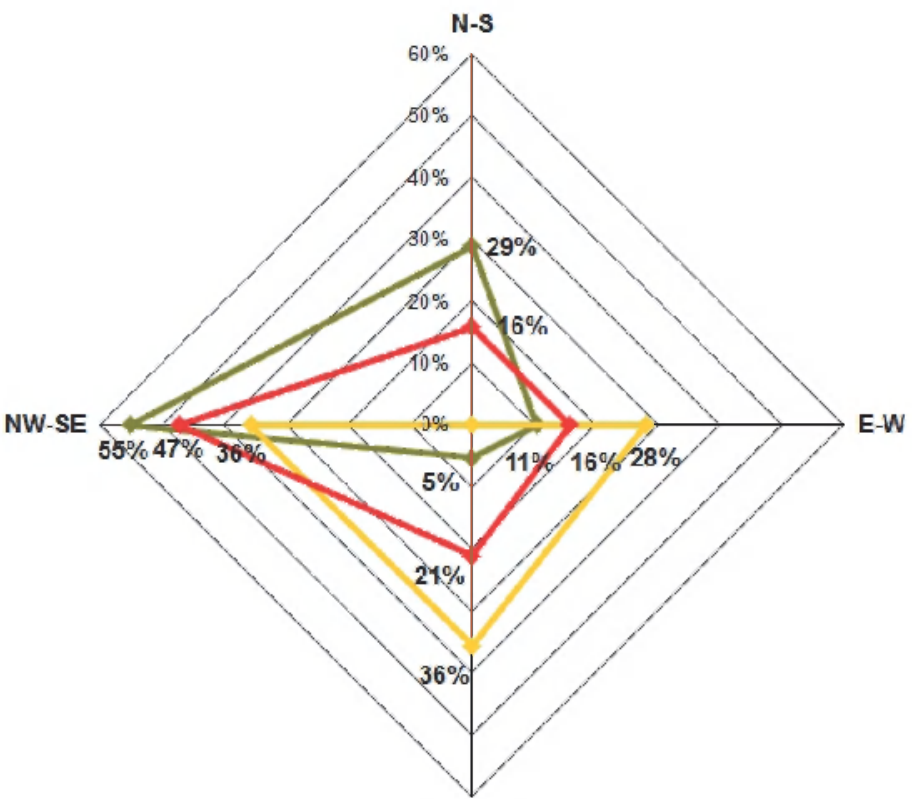

NE-SW -the Dudiowa Valley

$\rightarrow$ the Mt. Grzes

-llıe ML. Cserwory Wiench

Figure 14. Bearing of strata at particular study sites

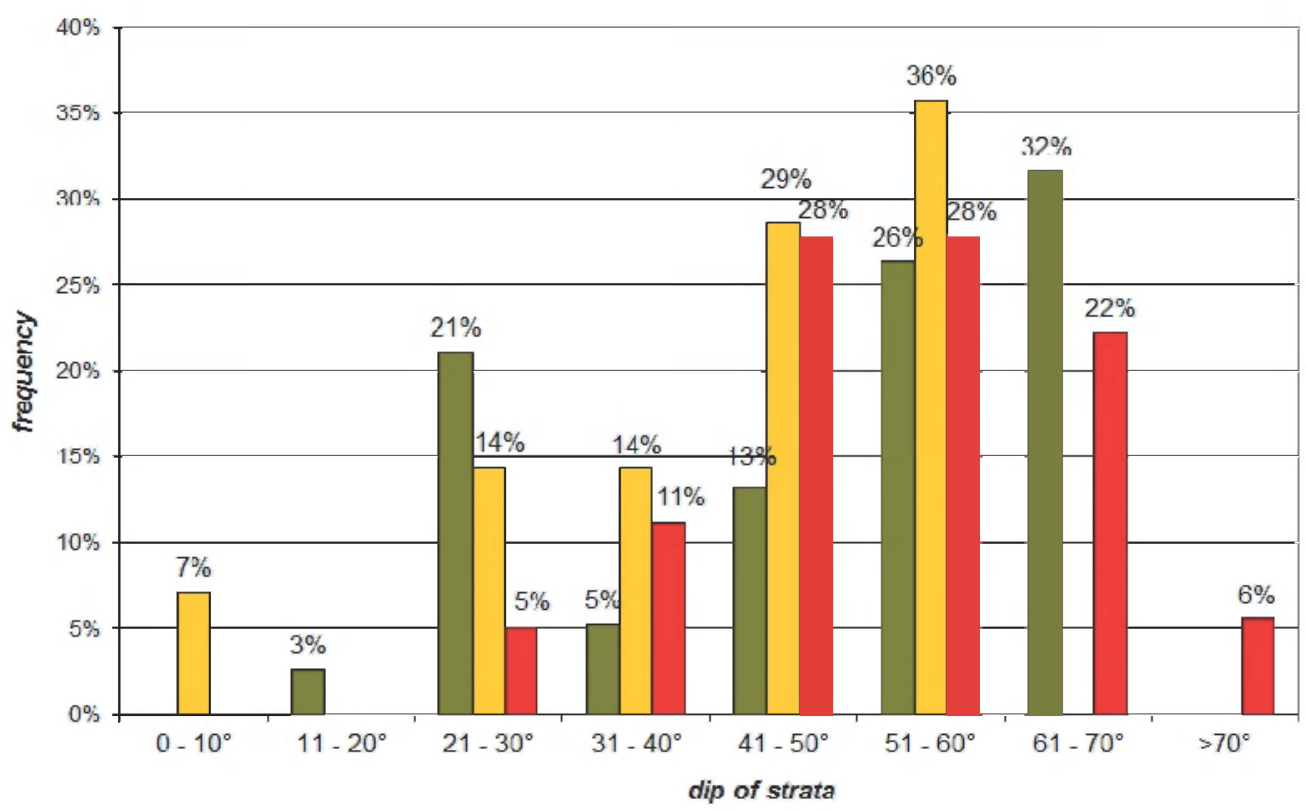

口the Dudowa Valley $\square$ the Mt. Greś $\square$ the Mt. Czerwony Wierch

Figure 15. Dip of strata at particular study sites 
Landforms located in the Dudowa Valley and upon Czerwony Wierch Mt. are typified by NW-SE strike of bedrock strata, unlike landforms situated upon the Grześ Mt., where attitudes of beds are variable (Fig. 14). In all groups of tors, bedrock strata dip relatively steeply $\left(40-70^{\circ}\right)$, while landforms occurring on the Grześ Mt. are typified by moderate dips of underlying strata (Fig. 15).

The dominant length of fissures is from a few dozen centimeters up to $1 \mathrm{~m}$, and their width usually ranges from several millimeters or centimeters to $10 \mathrm{~cm}$. Larger differences are noticeable in fissure density - the largest values typify dolomitic rocks of the Dudowa Valley. It results in differences in fraction and shape of debris material accumulated at the feet of rocks or on ledges within their walls. Debris material in the Dudowa Valley is predominantly finer and more angular than that on the Grzes Mt. and the Czerwony Wierch Mt. The rocks located on the Czerwony Wierch Mt. and on the Grześ
Mt. are characterized by the dominance of E-W orientation of fissures, while rocks located in the Dudowa Valley are cut by a network of differently oriented cracks. Another difference between groups of rock forms consists in frequent presence of subvertical fractures on the Czerwony Wierch Mt. and in the Dudowa Valley, with their almost total absence on the Grzes Mt. (Fig. 16).

In respect of the shape, rock towers dominate in all of the examined groups. However, on the Grzes Mt. and the Czerwony Wierch Mt. rocky ridges and block fields occur, which are absent in the Dudowa Valley. Rocks located in the Dudowa Valley are characterized by greatest diversity of form types. It is associated with the structure of the host blocky dolomite, dense network of fractures and the greatest, from among the examined rock types, susceptibility to weathering (Fig. 17).

Despite the fact that rock towers dominate within tors in all of the examined sites,

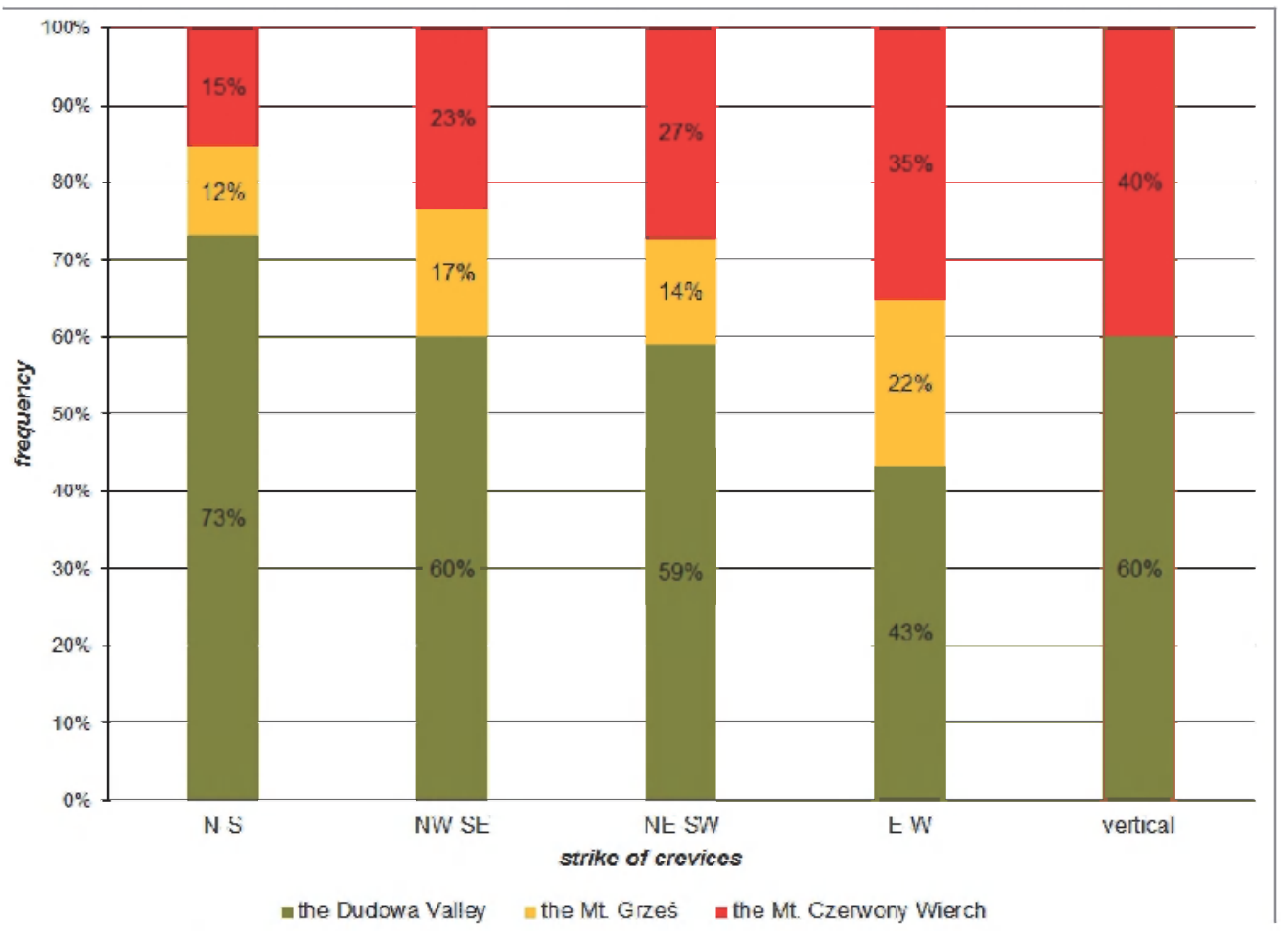

Figure 16. Orientation of fractures chtting tors at particular study sites 


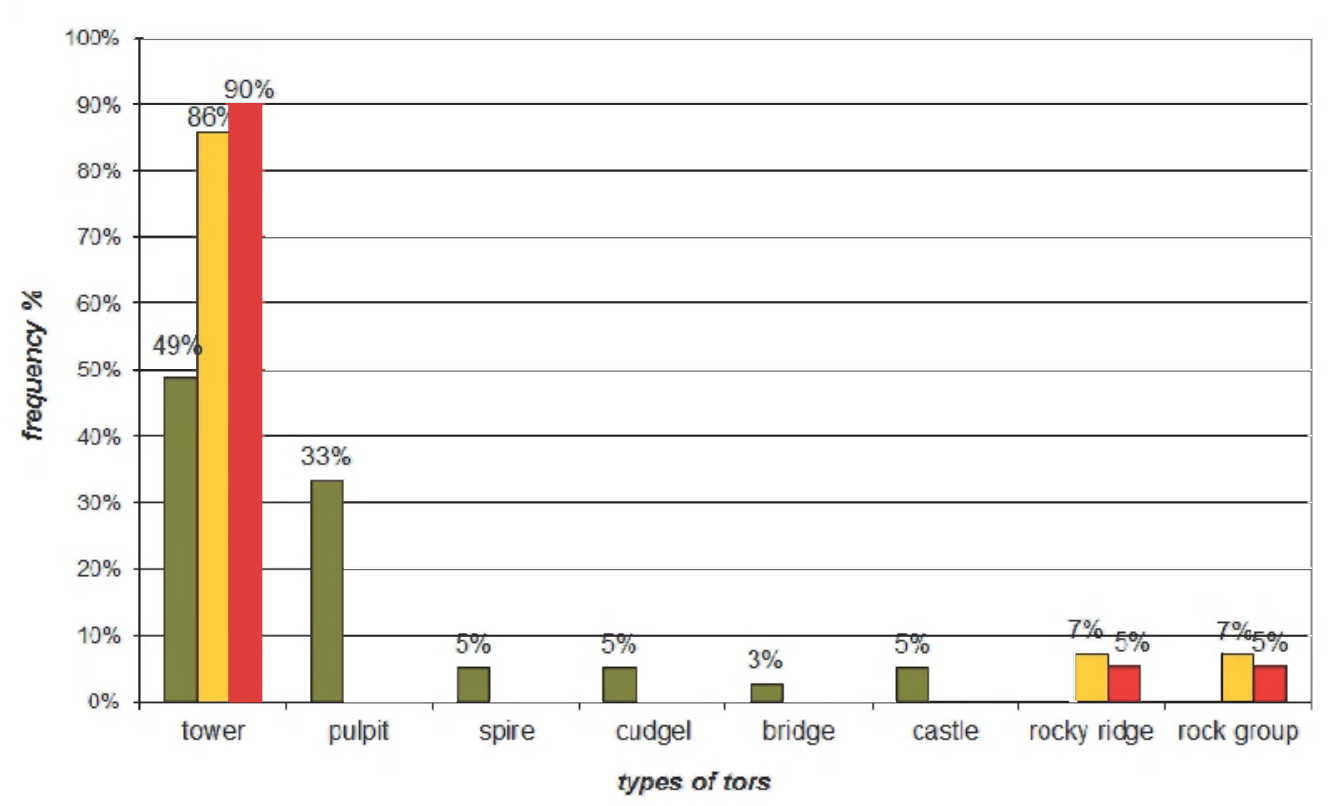

me Dudowa Valley $\square$ the Mt. Gzes athe Mt. Czelwony Wierch

Figure 17. Types of tors at particular study sites

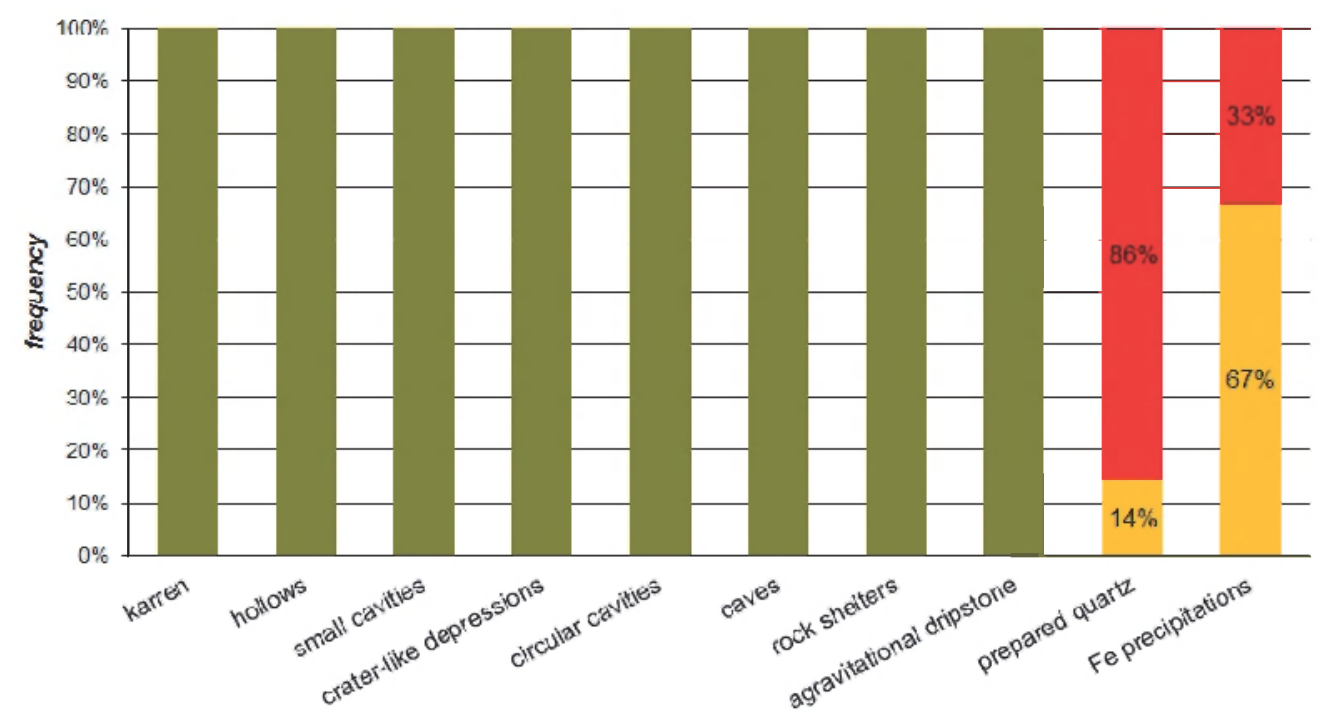

surface relief of tors

- the Dudowa Valley - Mt. Greś a Mt. Czerwony Wierch

Figure 18. Surface relief of tors at particular study sites, 
their substantial variety was noticed in respect to the size, degree of segmentation and wall inclination. Such differences are noticeable not only between different test areas but also within a given area. This is associated with the resistance of host bedrock, dip of strata, and concordance between strata dip and slope inclination.

The differences between average height and width of tors are small; the widths of rocks range from 1.3 to $9 \mathrm{~m}$ in the Dudowa Valley, 1.4 to $9 \mathrm{~m}$ on the Grześ Mt., and 3.5 to $11.3 \mathrm{~m}$ on the Czerwony Wierch Mt., whereas their heights are predominantly from 1 to $4 \mathrm{~m}$ on the Grześ Mt., 5 to $7 \mathrm{~m}$ on the Czerwony Wierch Mt., and 5 to $9 \mathrm{~m}$ in the Dudowa Valley. In the Dudowa Valley, one can also encounter landforms attaining 15-20 $\mathrm{m}$ in height and up to $100 \mathrm{~m}$ long, whereas on the Grześ Mt. these values are 10 $\mathrm{m}$ and $180 \mathrm{~m}$, respectively. Rocks of such size are absent from the Czerwony Wierch Mt. The relation of rocks' width to their height also attracts attention. On the Czerwony Wierch Mt. and Grześ Mt., a clear regularity occurs: tors are broader or longer rather than higher, while in the Dudowa Valley this relation is opposite.

Substantial differences between the examined groups of tors occur in the case of microrelief of their wall surfaces. The most diversified and best developed relief characterizes rocks located in the Dudowa Valley (Figs. 5, 6). Rocks located on the Grześ Mt. and on the Czerwony Wierch Mt. are characterized by poorly developed relief or a total lack of forms (Fig. 18). This is associated with the already mentioned role of diverse geological structure of rocks and their substantial resistance to weathering processes.

For the rate and effectiveness of geomorphic processes it is of great importance, in which altitudinal climatic belt a tor is located. The rocks of the Czerwony Wierch and a part of the Grzes forms are located in very cool and moderately cold altitudinal belt, where frost weathering is most intensive (Klimaszewski 1988; Kotarba 1972; Kotarba and Krzemien 1996). On the other hand, location of tors within the forest zone may lead to a reduction in the intensity of physical weathering and rockfall. This zone comprises rocks present on the Dudowa Valley sides and some of rocks located on the slope of the Grzes Mt. Rock landforms of all three assemblages are largely overgrown with various types of vegetation, occupying the upper parts of rocks and fissures, depressions and ledges within rock walls. The process of growing of spruce or mountain pine roots into the cracks, leading to faster rock disintegration, is frequently observed in the Dudowa Valley and on the Czerwony Wierch Mt., unlike in the case of tors located on the slope of the Grzes Mt.

\section{DISCUSSION AND CONCLUSIONS}

Tors have been dealt with by numerous scientific papers. Most frequently, these papers concern landforms developed upon sandstones, while publications dealing with granite or calcareous rocks are less frequent, focusing mainly on the issue of the origin of these landforms and, to a lesser extent, on rock shape, dimensions or microrelief.

The examined rocks are characterized predominantly by a small height, below 10 $\mathrm{m}$, whereas many rocks described in literature reach a few dozen meters. In the case of rocks located on the slope of the Czerwony Wierch Mt. and some of the rocks situated on the slope of the Grzes Mt., the difference also consists in a smaller compactness of landforms in respect to their shape. It is associated with the location of the examined landforms above the upper timberline, in a very cool and moderately cold altitudinal belt. The Tatra rocks are also characterized by a less clearly developed microrelief of rock wall surfaces. This fact was already noticed by M. Wieczorek (1999). The landforms built up of resistant quartzitic sandstones, compared to those developed on sandstones of the Carpathian Foothills, Flysch Carpathians or Sudetes, are typified by the lack of microforms of arcade structure type, spongy, cavernous, cellular and other microforms, which were described, among others, 
by Z. Alexandrowicz (1963a, b, c; 1964a, b; 1970), Z. Alexandrowicz et al. (1975, 1996), Z. Alexandrowicz and E. Brzeźniak (1989), and P. Migon (2005). On the contrary, the nearly complete lack of microforms on the surface of rock forms present on the slope of the Czerwony Wierch Mt. is consistent with observations made by A. Jahn (1962) in the Karkonosze Mountains and in the Jelenia Góra Basin.

In spite of the above mentioned differences between tors located on the Dudowa Valley sides and the Grześ Mt. and Czerwony Wierch Mt. slopes and other rocks discussed in the literature, they have some common characteristics. The location of rocks examined in this paper is similar to that of rocks described by other authors. The rocks are located predominantly on ridges or slopes in a staircase-like manner (one over another), and they usually form clusters instead of single landforms. As in the Dudowa Valley and on the Grześ Mt. and Czerwony Wierch Mt., the most common type of rock, in terms of shape, is rock tower or pulpit (depending on the adopted classification). According to A. Sobczyk (2008), the shape of landforms is determined primarily by geological structure, and the density and type of fractures. The conducted study seems to confirm this statement; it is impossible to indicate explicit dependencies of the shape of the characterized rocks, either on their location in the area, or on exposure. On the other hand, the impact of differences in geological structure and form fracturing is visible.

The results of field studies indicate that the examined assemblages of rocks are typified by low mutual similarity. The greatest (though minimal) similarity is observed in the rock assemblages occurring on the Grzes Mt. and Czerwony Wierch Mt., while the Grzes Mt. and Dudowa Valley assemblages show the greatest differences.

On the basis of the conducted field studies, an attempt can be made to distinguish several development stages of tors in the Tatra Mountains. During the first stage, the landforms are
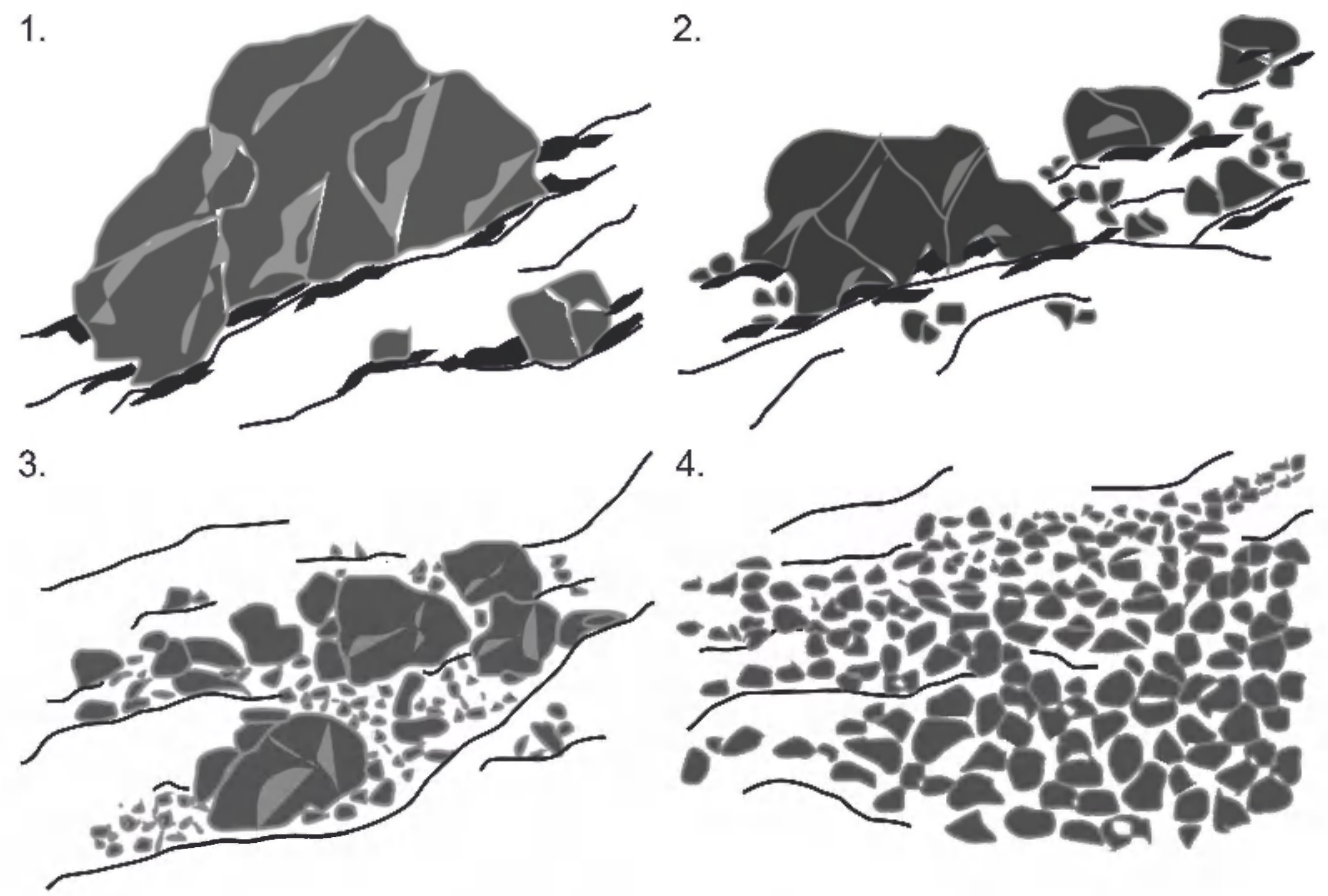

Figure 19. Stages of tors development 
dismembered to a small degree and they constitute a relatively compact block of a substantial size. With time, as a result of a number of morphogenetic processes, a significant rock segmentation into a number of smaller "fragments" occurs, between and in the vicinity of which debris covers develop. The third stage leads to development of a block field, which is composed of unsorted clasts of variable diameters. Then, the shaping of debris covers follows. These covers comprise small-size clasts of comparable dimensions that occupy large parts of the slope (Fig. 19).

The proposed scheme of tors development is most appropriate for rocks located above the upper timberline, where the effects of frost weathering are more effective than in the case of forms located within the forest zone. Also, rocks will be transformed in a slightly different manner, if an important role in their modeling is performed by karst processes.

\section{REFERENCES}

Alexandrowicz, S. W. and Alexandrowicz, Z. (2003), Skałki wapienne Doliny Kamienic na Wyżynie Krakowskiej [Calcareous tors of the Dolina Kamienic Valley in the Kraków Upland], Chronmy Przyrode Ojczysta, 59, 6:40-56.

Alexandrowicz, S. W. and Alexandrowicz, Z. (2004), Ewolucja rzeźby i środowiska Praskowyżu Ojcowskiego [Evolution of relief and envitonment of the Ojców Plateau], in Partyka, J. (ed.), Zróżnicowanie i przemiany środowiska przyrodniczo-kulturowego Wyżyny Krakowsko-Częstochowskiej [Diversity and transformations of natural and cultural environment of Kraków-Częstochowa Upland], Przyroda, Ojców, 1: 47-54.

Alexandrowicz, Z. (1963a), Baszta skalna na Zarze w Beskidzie Małym [Rock tower on Zar Mt. in the Little Beskid], Chronmy Przyrode Ojczysta, 19, 2: 45-47.

Alexandrowicz, Z. (1963b), Najpiękniejszy zabytek przyrody nieożywionej w Beskidzie Małym [The most beautiful monument of inanimate nature in the Little Beskid], Chronmy Przyrodę Ojczysta, 19, 3: 42-44.
Alexandrowicz, Z. (1963c), Skałki fliszowe w rezerwacie Madohora [Flysch tors in Madohora Reserve], Chronmy Przyrode Ojczysta, 19, 6:47-49.

Alexandrowicz Z. (1964a), Ruinowe skatki fliszowe w okolicy Krzeszowa [Ruin flysch tors near Krzeszów], Chronmy Przyrodę Ojczysta, $20,3: 48-49$.

Alexandrowicz, Z. (1964b), Zwalisko skalne na zachodnim stoku Madohory [Rock ruins on the Southern slope of Madohora], Chronmy Przyrode Ojczysta, 20, 2: 49-52.

Alexandrowicz, Z. (1970), Skatki piaskowcowe w okolicy Ciężkowic nad Białą [Sandstone rocks in the vicinity of Ciężkowice on the Biała River], Ochrona Przyrody, 35: 281-335.

Alexandrowicz, Z. (1982), Skałki piaskowcowe Gorczańskiego Parku Narodowego i jego otoczenia [Sandstone tors of the Gorce National Park and its surroundings], Ochrona Przyrody, 44: 293-316.

Alexandrowicz, Z. (ed.) (1996), Geoochrona Beskidu Sądeckiego i Kotliny Sądeckiej [Geopreservation of the Sącz Beskid and Sącz Basin], Studia Naturae, 42: 32-119.

Alexandrowicz, Z. and Brzeźniak E. (1989), Uwarunkowanie procesỏw wietrzenia na powierzchni skałek piaskowcowych w wyniku zmian termiczno-wilgotnościowych w Karpatach fliszowych [Determinants of weathering processes on surface of sandstone rocks due to thermo-humidity changes in the Flysch Carpathian Mountains], Folia Geographica, series geographicasphysica, 21: 17-35.

Alexandrowicz, Z., Drzat, M. and Kozłowski, S. (1975), Katalog rezerwatów i pomników przy tody nieożywionej w Polsce [Catalogue of reserves and monuments of inanimate nature in Poland], PWN, Warszawa, Kraków, 1-298.

Bajgier, M. (1991), W sprawie genezy skalek w masywie granitowym Dartmoor w Anglii [Concerning origin of rocks in Dartmoor Granite Massif in England], Folia Geographica, series geographica-physica, 22: 25-34.

Bajgier-Kowatska, M. (2002), Formy skałkowe jako element rzeźby osuwiskowej w Beskidzie Zywieckim [Tors as element of landslide morphology in the Żywiec Beskid], Acta Universitatis Nicolae Copernici, 32, Geografia, 109: 31-45.

Czarnocki, J. (1932), Mniej znane zabytki Gór Świętokrzyskich [Less known monuments of 
the Swiętokrzyskie Mountains], Ochrona Przyrody, 12: 74-81.

Czeppe, Z. (1952), Z morfologii Gór Stołowych [From Morphology of the Stolowe Mountains], Ochrona Przyrody, 20: 236-251.

Drzal, M. (1955a), Kamień pod Leskiem [Rock near Lesko], Chrońmy Przyrodę Ojczysta, 11, 5: $52-53$.

Drzał M. (1955b), Skalki na wzgórzu Wieprzyk Las koło Ciężkowic [Rocks on Wieprzyk Hill Forest near Ciężkowice], Chrońmy Przyrode Ojczysta, 11, 6: 37-39.

Dudziak, J. (1960), Kornuty - rezerwat skalny w Beskidzie Niskim [Kornuty - Rock reserve in the Low Beskid], Chronmy Przyrode Ojczysta, 16, 1: 45-47.

Hornig, A. (1955), O niektórych zabytkach przyrody nieożywionej Wyżyny Śląskiej [On some monuments of inanimate nature of the Silesian Upland], Chronimy Przyrodę Ojczysta, 11, $6: 8-18$.

Jahn, A. (1962), Geneza skałek granitowych [Origin of Granite Rocks], Czasopismo Geograficzne, 33, 1: 19-40.

Jahn, A. (1985), Karkonosze Polskie [Polish Karkonosze Mountains], PAN, Wrocław, Warszawa, Kraków, Gdańsk, Lódź, p. 59-62.

Kęsik, A. (1955), O ochronę zabytków skalnych Srodkowego Roztocza [For preservation of rock monuments of Central Roztocze], Chróniny Przyrodé Ojczysta, 11, 6: 19-24.

King, L.C. (1948), A theory of bornhardts, Geographical Joumal, 112: 83-87.

Klimaszewski, M. (1932), Grzyby skalne na Pogórzu Karpackim między Rabą a Dunajcem [Rock mushrooms in Carpathian Foothills between the Raba river and the Dunajec River], Ochrona Przyrody, 12: 64-70.

Klimaszewski, M. (1947), Osobliwości skalne w Beskidach Zachodnich [Rock peeculiarities in the Western Beskids], Wierchy, 17: 57-77.

Klimaszewski, M. (1988), Rzeźba Tatr Polskich [Morphology of the Polish Tatra Mountains], Wydawnictwa Naukowe PWN, Warszawa, p. $1-668$.

Kotarba, A. and Krzemień, K. (1996), Rzeźba Tatr oraz jej postglacjalna ewolucja - stan i perspektywy badan geomorfologicznych [Relief of the Tatra Mts. and its postglacial evolution - state of the art and perspec- tives of future geomorphological studies], in Kotarba, A. (ed.), Przyroda Tatrzańskiego Parku Narodowego a czlowiek [Environment of the Tatra National Park and Man], 1, Nauki o Ziemi [Earth Sciences], TPN, Kraków, Zakopane, p. 45-55.

Lindner, L. (1972), Geneza i wiek skałek piaskowcowych Góry Pieklo kolo Niekłania [Origin and age of sandstone rocks of Piekto Mountain Near Niekłań], Acta Geologica Polonica, 22: 169-180.

Linton, D.L. (1955), The problem of tors, Geographical Journal, 121: 470-487.

Migoń, P. (2005), Piaskowcowe formy skalne w okolicach Krzeszowa w Sudetach Srodkowych [Sandstone rock formations in the vicinity of Krzeszów. Middle Sudetes], Chrońmy Przyrode Ojczysta, 61, 2: 79-89.

Palmer, J. and Radley, J. (1961), Gritstone tors of English Pennines, Zeitschrift für Geomorphologie, 5,1:37-52.

Sobczyk, A. (2006), Rzeźba skałkowa - poglądy na genezę skalek oraz stan badań w Polsce [Tors morphology - views on tors origin and state of studies in Poland], Przeglad Geograficzny, 78: 365-381.

Walczak W., (1963), Geneza form skalnych na pólnocno-wschodniej krawędzi Gór Stolowych [Genesis of tors on the northeastern border of the Stolowe Mountains], Acta Universitatis Wratislaviensis, Studia geograficzne, 1, 9: 191-200.

Walczak, W. and Stec, T. (1954), Karkonosze. Zarys monograficzny [Karkonosze Mountains. A monographic outline], Sport i Turystyka, Warszawa.

Wieczorek, M. (1999), Typologia form skalkowych na przykladzie wybranych obszarow w Dolinie Chocholowskiej w Tatrach Zachodnich [Typology of rock forms on the example of selected areas in the Chocholowska Valley in the Western Tatra Mts.]. Unpublished M.Sc. thesis, Institute of Geography and Spatial Management, Jagiellonian University, Kraków.

Whatley, W.B. and Warke, PA. (2005), Weathering, in Selley, R.C. (ed.), Encyclopedia of geology, 5, Elsevier, Oxford: 581-590.

Paper first received: October 2010

In final form: October 2011 
http://rcin.org.pl 